Egypt. J. of Appl. Sci., 35 (11) 2020

$164-173$

\title{
EXOPOLYSACCHARIDE PRODUCTION, EXTRACTION, AND CHARACTERIZATION FROM \\ SOIL ISOLATE Bacillus spp.
}

Ahmed Farag ${ }^{1}$; Walaa Gamil ${ }^{2}$ and Ehab Essawy ${ }^{3}$

${ }^{1}$ Microbiology Department, Faculty of Science, Helwan University, 11795, Cairo, Egypt.

${ }^{2}$ Biochemistry Master Program, Chemistry Department, Faculty of Science, Helwan University, 11795, Cairo, Egypt.

${ }^{3}$ Chemistry Department, Faculty of Science, Helwan University, 11795, Cairo, Egypt.

Key Words: Exopolysaccharides, 16srRNA, HPLC, FTIR.

\section{ABSTRACT}

Exopolysaccharides (EPS) possess a reducing power that applied in a wide range of biotechnological applications, like biosynthesis of nanoparticles. In presented work, two samples from different plant soils (clover and wheat) were collected for screening of EPS producing strain. Our results showed that, only one colony of wheat soil formed a mucoid surface on agar plates, this strain was identified morphologically and confirmed by molecular characterization using 16srRNA as Bacillus pp. The ethanolic extract of EPS had been characterized by High performance liquid chromatography (HPLC) and Fourier transforminfrared spectroscopy (FTIR). Our finding opens the door for utilizing Bacillus Spp. as a promising natural source for EPS production.

\section{INTRODUCTION}

Microbial exopolysaccharides (EPS) are natural, non-toxic, and biodegradable polymers produced and secreted by microbial cells to their surrounding environment. Polysaccharides produced by microbes can be generally classified by their biological functions into intracellular storage polysaccharides (glycogen), capsular polysaccharides which are closely linked to the cell surface (CPS) and extracellular bacterial polysaccharides also termed exopolysaccharide (EPS) which form a slime layer loosely attached to cell surface or secreted into environment (for example, xanthan, sphingan, alginate, cellulose, etc.) .Various groups of microorganisms are known to produce exopolysaccharides such as bacteria (including extreme and marine bacteria) (Laurienzo, 2010; Nicolaus et al., 2010) cyanobacteria (Laurienzo, 2010), fungi and yeasts (Mahapatra \& Banerjee, 2013). EPS synthesis play crucial biological roles in maintaining viability of microbial cell. Among these functions include adhesion to solid surfaces, cell-cell interactions, forming biofilm on the surfaces to increase cell protection against environmental extremes (Ates, 2015). The production of polysaccharides by microbes is achieved within days and weeks as opposed to plants where production takes 3-6 months (Donot et al., 2012). Recently, the structure and properties of microbial exopolysacchar ide have attracted the scientific community, 
making them more suitable for bio nanotechnology and commercial applications in different industrial sectors like food, petroleum, and pharmaceuticals. The synthesis and stabilization of metal nanoparticles using microbial exopolysaccharide was of interest because EPS contain various functional groups that can act as reductive and stabilizing agents via a chelating and capping process in the synthesis of metal nanoparticles (Emam \& Ahmed, 2016). The object of this study was to screen and isolate efficient EPS producing strain and to characterize extracted exopolysaccharide.

\section{Samples Collection}

\section{MATERIALS AND METHODS}

Two soil samples were collected from the village of Senourse, Faiyum governorate, Egypt (Figure 1). The first clover soil sample and the second wheat soil sample. All soil samples have been collected in sterile plastic bags and stored at $4{ }^{\circ} \mathrm{C}$ for further analysis.

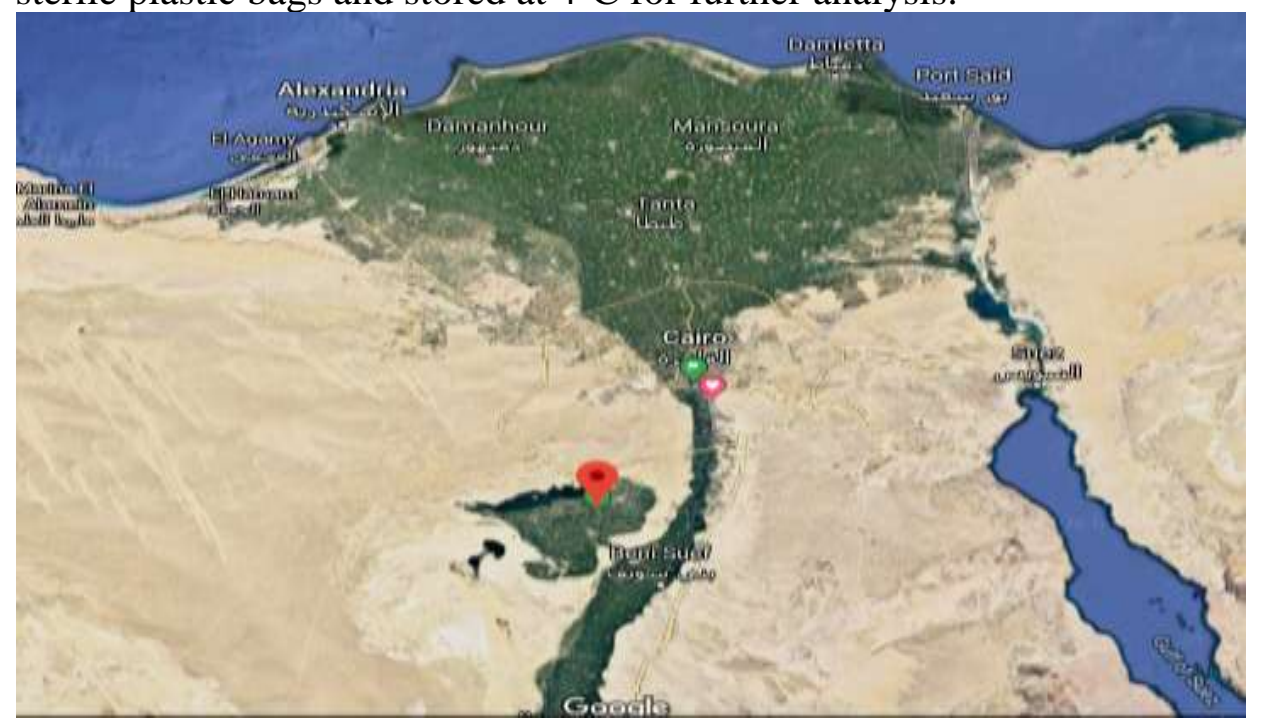

Figure 1. Location of Senourse village, Fayoum. $29.3858558,30.8651253$

\section{Isolation, Screening and Identification of Exopolysaccharide Producing Strain}

The soil samples collected were used as the primary inoculum for the isolation of bacterial strains. One gram of each soil was added to $9 \mathrm{ml}$ of sterile distilled water for soil suspension. Serial dilutions $\left(10^{-1}\right.$ to $\left.10^{-7}\right)$ were performed and then inoculated on nutrient agar plates containing the following components $(\mathrm{g} / \mathrm{l})$ : peptone $5.0 \mathrm{~g}$, beef extract $3.0 \mathrm{~g}$, sodium chloride $5.0 \mathrm{~g}$ and agar $15.0 \mathrm{~g}$. For each soil sample, inoculated plates were 
incubated at $37^{\circ} \mathrm{C}$ for $24 \mathrm{~h}$. Colonies with different morphological characters have been collected and cultivated for further purification. The pure exopolysaccharide (EPS) colonies producing bacteria have been spread over modified nutrient agar media containing peptone $5.0 \mathrm{~g}$, beef extract 3.0 $\mathrm{g}$, agar $15.0 \mathrm{~g}$, sodium chloride $5.0 \mathrm{~g}$, sucrose $40 \mathrm{~g}$ and distilled $1000 \mathrm{ml}$ of water and incubated for $72 \mathrm{~h}$ at $30^{\circ} \mathrm{C}$ (Pawar et al., 2013). Exopolysaccharide strain was selected by observation of mucoid colony (Fusconi \& Godinho, 2002) and was named SN-2.

\section{Identification of Exopolysaccharide Producing strain}

Gram staining was used to determine morphological properties such as colony color, colony shape, gram stain and cell shape were observed under light microscope. A strain was confirmed by molecular characterization using 16s rRNA. Genomic DNA was extracted by the TE boil extraction method for molecular characterization of the isolated strain (Li et al., 2003). Two universal oligonucleotides bacterial primers (16S rRNA forward primer: 5-GAG TAA TGT CTG GGA AAC TGC CT-3 and16S rRNA reverse primer: 5 CCA GTT TCG AAT GCA GTT CCC AG-3) were used.

The PCR conditions used in the amplification of $16 \mathrm{~S}$ rRNA genes were the initial denaturation of $95^{\circ} \mathrm{C}$ for $5 \mathrm{~min}$ followed by 35 cycles of 95 ${ }^{\circ} \mathrm{C}$ for $1.5 \mathrm{~min}, 59^{\circ} \mathrm{C}$ for $1 \mathrm{~min}$ and $72^{\circ} \mathrm{C}$ for $1.5 \mathrm{~min}$, with the final 10 min extension at $72^{\circ} \mathrm{C}$. The $16 \mathrm{~S}$ rRNA gene sequences were compared to those of the GeneBank and EMBL databases by advanced BLAST (Megablast) searches from the National Center for Biotechnology Information (NCBI). The phylogenic relationship of the isolate was determined by comparing the sequencing data with the related 16S rRNA gene sequences in the GeneBank database of the National Center for Biotechnology Information, via BLAST search. The phylogenetic tree was constructed by the Geneious Pro 8.9 programs.

\section{EPS Production and Extraction}

Production of EPS was carried out by active growing inoculum of isolated bacterial strains with inoculum size $(100 \mu \mathrm{l})$ in a $250 \mathrm{ml}$ bottle containing $100 \mathrm{ml}$ of $4.0 \mathrm{~g}$ sucrose NB, $0.5 \mathrm{~g}$ peptone, $0.3 \mathrm{~g}$ beef and $0.5 \mathrm{~g}$ $\mathrm{NaCl}$ and $\mathrm{pH}$ adjusted to 7.5. Bacterial culture was incubated at Bulgara Shaking incubator ${ }^{\circledR}$ Model: VS-8480 at $35^{\circ} \mathrm{C}$ fo $4 . \mathrm{r} 72$ hours at $150 \mathrm{rpm}$. EPS extraction was achieved by a (Pawar et al., 2013) minor modification method, where the cells were removed by cooling centrifugation (Sigmas 3$16 \mathrm{PK}$ ) at $10,000 \mathrm{rpm}$ for $20 \mathrm{~min}$ at $4{ }^{\circ} \mathrm{C}$. The EPS was precipitated by adding a double volume of refrigerated absolute ethanol to the cell-free culture and kept at $4^{\circ} \mathrm{C}$ overnight. Ethanol extract was centrifuged at 10,000 rpm at $4^{\circ} \mathrm{C}$ for 20 min, crude EPS was collected and dried at $60^{\circ} \mathrm{C}$. 


\section{Characterization of EPS}

Sugar monomers in EPS have been characterized by the use of highperformance liquid chromatography (HPLC) Shimadzu Class-VPV 5.03 (Kyoto, Japan) equipped with a refractive index RID-10A Shimadzu detector, L-C-16ADVP binary pump and PL Hi-Plex Pb column (Bebault et al., 1973). EPS was subjected to hydrolysis by $2 \mathrm{~N}$ sulfuric acid for $24 \mathrm{~h}$. The precipitate was filtered off at the end of the hydrolysis. Barium carbonate was used for precipitation removal of sulfate from the filtrate. The hydrolysate was evaporated under vacuum by means of a rotary evaporator to produce residues that were dried and extracted with hot distilled pyridine. The pyridine extract was evaporated to dryness and the residues were stored at $4^{\circ} \mathrm{C}$ for HPLC analysis. Functional groups present in the purified EPS were determined by Fourier transform infrared (FTIR) spectroscopy (PerkinElmer ATR Sample Base Plate DIAMOND spectrometer) equipped with $\mathrm{KBr}$ beam splitter with MIR TGS detector $\left(4000-450 \mathrm{~cm}^{-1}\right)$ at the Central Lab, Faculty of Science, Helwan University, Egypt (Sterner et al., 2008) .

\section{RESULTS}

\section{Isolation and Screening of Exopolysaccharide producing bacteria}

Two samples from different plant soils (clover and wheat) were used to screen EPS strains, spread pure different colonies for each soil sample over a modified nutrient agar medium containing 4 percent sucrose, and incubated at $30^{\circ} \mathrm{C}$ for 72 hours. After incubation period the isolated five colonies from clover soil didn't show any mucoid surface on the nutrient agar plates, however only one colony of wheat soil showed a mucoid surface on the agar plates this an indication of EPS production as showed in Figure 2 this strain named as $\mathrm{SN}-2$ was inoculated on nutrient slant and maintained at $4^{\circ} \mathrm{C}$ further characterized by morphological and molecular characterization.

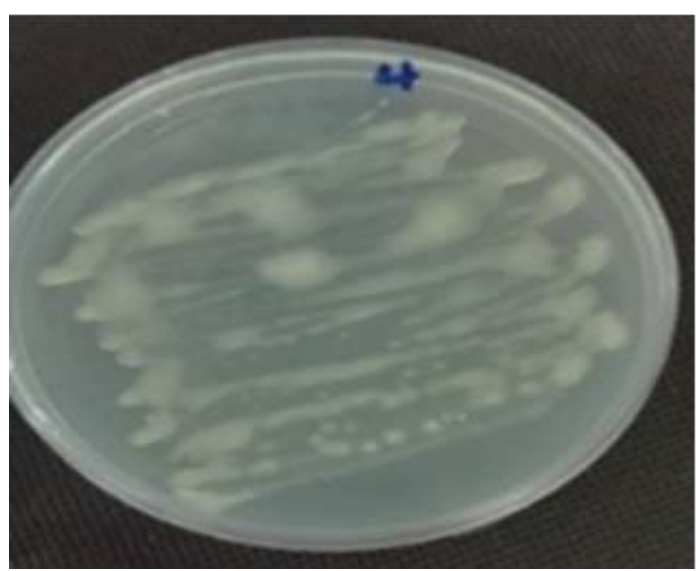

Figure 2: Mucoid layer of isolated strain on nutrient plate. 


\section{Morphological and Molecular Characterization of isolated strain}

The strain-producing bacterial exopolysaccharide was identified on the basis of morphological character as gram-positive rod-shaped bacteria. Further confirmation was made using molecular characterizations. The RNA of the strain was amplified with universal primers. Purified PCR products have been sequenced in one direction using forward universal primers. Based on the alignment of 16S rRNA gene sequences from the GeneBank database and the phylogenetic tree, the 16S rRNA gene sequence of the strain showed the highest similarity to Bacillus spp with a 97.5 percent sequence identity.

\section{Characterization of bacterial EPS}

The functional groups of the EPS were characterized by Fourier Transform Infrared (FTIR) spectroscopy. The spectrum (Figure 3) showed peaks at 3293, 2926, 2132, 1811, 1721, 1633, 885 and 724 $\mathrm{cm}^{-1}$. The strong band at $3289 \mathrm{~cm}^{-1}$ may correspond to broad stretching $\mathrm{O}-\mathrm{H}$ group; the peak at $2922 \mathrm{~cm}^{-1}$ is corresponding to C-H stretching peak of methylene groups, and the band at $1727 \mathrm{~cm}^{-1}$ may due to $\mathrm{C}=\mathrm{O}$ vibrations. The monosaccharide units of the EPS extract were determined by high performance liquid chromatography (HPLC). The extract contains mainly galactose (80.3\%) and glucose (19.7\%). Standard peaks of galactose and glucose correspond to peaks of tested EPS respectively was found during the analysis (figure 4).

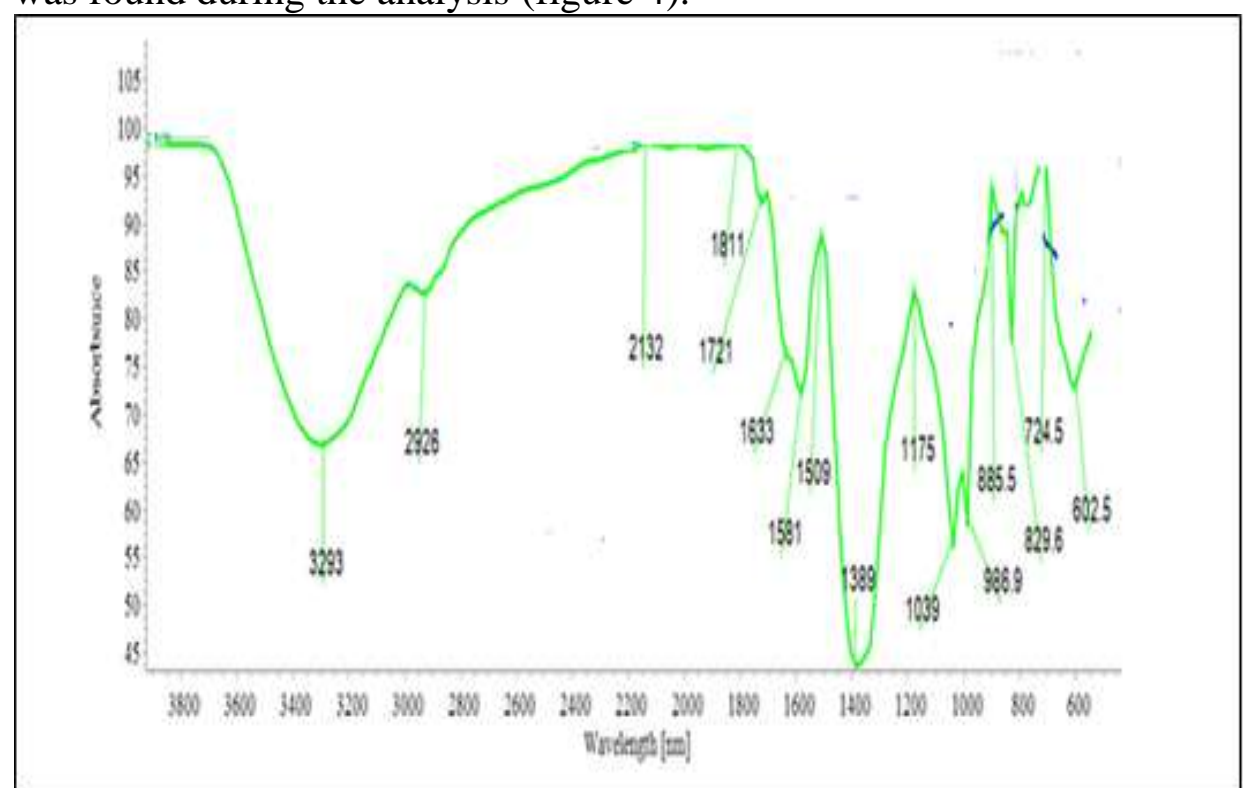

Figure 3: FTIR Chart of exopolysaccharide extracted from Bacillus spp . 


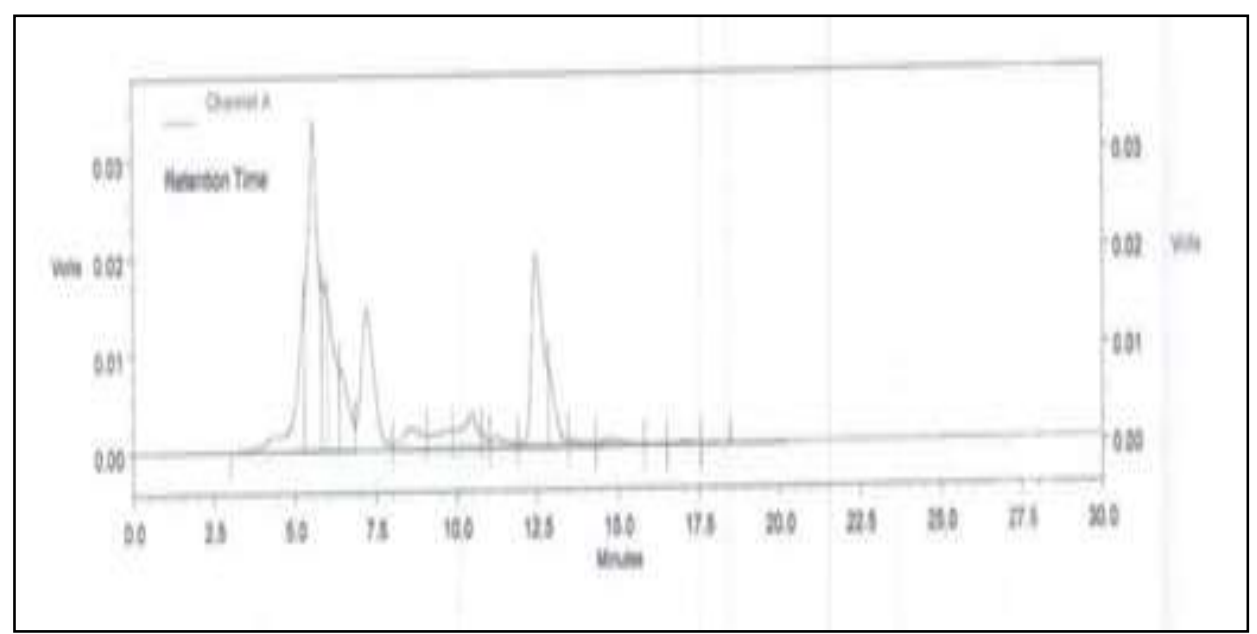

Figure 4: HPLC chromatogram of exopolysaccharide extracted from

\section{Bacillus Spp.}

\section{DISCUSSION}

Soil contains varieties of microorganism including bacteria that can be established in any natural environment. A wide range of bacteria are known to produce exopolysaccharides. Some studies approached to produce exopolysaccharides (EPS) by bacterial species isolated from soil. As appeared in study of (Sirajunnisa \& Surendhiran, 2014), this study interested to use bacterial strain isolate (Pseudomonas fluorescens) isolated from soil as source of exopolysaccharide and study of (Shukla \& Patel, 2015) which showed production of exopolysaccharide by Bacillus coagulans isolated from soil (Benson, 2002) . During our screening program for exopolysaccharide production from bacteria, only one bacterial strain showed a slimy surface , (an indication of EPS production) (Fusconi \& Godinho, 2002). The use of 16S rRNA gene sequencing in the clinical laboratory play a very important role in identifying biochemically unidentified bacteria or for providing reference identifications for unusual strains (El-Batal et al., 2016) .The DNA of the isolated strain was amplified with universal primers. showed that the PCR product was $521 \mathrm{bp}$. Based on the alignment of 16S rRNA gene sequences from the Gene Bank database and the phylogenetic tree, the 16S rRNA gene sequence of the strain showed the highest similarity to Bacillus spp with a 97.5 percent sequence identity.

The functional groups of the EPS were characterized by FT-IR spectroscopy. The spectrum showed the strong band at $3293 \mathrm{~cm}^{-1}$ may correspond to broad stretching O-H group; the peak at $2926 \mathrm{~cm}^{-1}$ is 
corresponding to $\mathrm{C}-\mathrm{H}$ stretching peak of methylene groups, and the band at $1721 \mathrm{~cm}^{-1}$ may due to $\mathrm{C}=\mathrm{O}$ vibrations. These bands are related to the sugar ring and is accountable for the solubility of EPS in water (Galvez et al., 2019). The detected $\mathrm{C}-\mathrm{H}$ stretching peak is corresponding to the hexoses such as glucose or galactose (Castellane et al., 2015). The set of bands between 1047 and $616 \mathrm{~cm}^{-1}$ can be used to describe polysaccharides (Wang et al., 2018). The monosaccharide units of the EPS extract were determined by high performance liquid chromatography (HPLC). The extract contains mainly galactose $(80.3 \%)$ and glucose $(19.7 \%)$. It was reported that most of the exopolysaccharides (EPS) mainly composed of galactose and glucose as well as some other sugars like rhamnose, gluconic acids, and amino sugars (Roca et al., 2015; Sathiyanarayanan et al., 2017).

\section{CONCLUSION}

The isolated strain from wheat plant soil showed a mucoid surface on nutrient agar plate and used as source of EPS production. The exopolysaccharide produced by bacteria in broth media was extracted by ethanol and characterized by FTIR which shows the presence of $\mathrm{O}-\mathrm{H}$ group methylene groups, and $\mathrm{C}=\mathrm{O}$ vibrations. The sugar monomers of EPS were characterized by HPLC. The extract contains mainly galactose $(80.3 \%)$ and glucose $(19.7 \%)$. Hence, the resultant product could be utilized in biotechnological applications.

\section{REFERENCES}

Ates, O. (2015). "Systems biology of microbial exopolysaccharides production". Frontiers in Bioengineering and Biotechnology, 3, 200.

Bebault, G. M.; J. M. Berry; Y. M.Choy; G. G. S. Dutton ; N. Funnell ; L.D. Hayward and A.M.Stephen (1973). "Semimicro determination of sugar configuration by measurement of circular dichroism of alditol acetates". Canadian Journal of Chemistry, 51(2): 324-326.

Benson, H. J. (2002). "Microbiological Applications Laboratory Manual in General Microbiology". The McGraw- Hill Companies.

Castellane, T.C.L.; A.M.M.B.Otoboni and E.G.deM.Lemos (2015). "Characterization of Exopolysaccharides Produced by Rhizobia Species". Revista Brasileira de Ciência Do Solo, 39(6): 15661575.

Donot, F. ; A. Fontana ; J. C. Baccou and S.Schorr-Galindo (2012). Microbial exopolysaccharides: main examples of synthesis, 
excretion, genetics and extraction. Carbohydrate Polymers, 87(2): 951-962.

El-Batal, A.I. ; H.H. El-Hendawy and A.H. Faraag (2016). Synthesis and characterization of silver nanoparticles by Serratia marcescens strains isolated from different sources in Egypt. Nature and Science, 14(12): 205-215.

Emam, H. E. and H.B. Ahmed, (2016). Polysaccharides templates for assembly of nanosilver. Carbohydrate Polymers, 135, 300-307.

Fusconi, R. and M.J.L. Godinho (2002). Screening for exopolysaccharide-producing bacteria from sub-tropical polluted groundwater. Brazilian Journal of Biology, 62(2): 363369.

Galvez, A.M.; K.M. Ramos; A.J. Teja and R. Baculi (2019). Bacterial exopolysaccharide-mediated synthesis of silver nanoparticles and their application on bacterial biofilms. Journal of Microbiology, Biotechnology and Food Sciences, 8(4): 970-978.

Laurienzo, P. (2010). Marine polysaccharides in pharmaceutical applications: an overview. Marine Drugs, 8(9), 2435-2465.x

Li, M. ; J. Gong ; M. Cottrill ; H. Yu ; C. de Lange ; J. Burton and E.Topp (2003). Evaluation of QIAamp® DNA Stool Mini Kit for ecological studies of gut microbiota. Journal of Microbiological Methods, 54(1): 13-20.

Mahapatra, S. and D. Banerjee (2013). Fungal exopolysaccharide: production, composition and applications. Microbiology Insights, 6, MBI-S10957.

Nicolaus, B. ; M. Kambourova and E.T. Oner (2010). Exopolysaccharides from extremophiles: from fundamentals to biotechnology. Environmental Technology, 31(10): 1145-1158.

Pawar, S.T. ; A.A.Bhosale ; T.B. Gawade and T.R. Nale (2013). Isolation, screening and optimization of exopolysaccharide producing bacterium from saline soil. Journal of Microbiology and Biotechnology Research, 3(3): 24-31.

Roca, C. ; V.D.Alves ; F. Freitas and M.A.M. Reis (2015). Exopolysaccharides enriched in rare sugars: Bacterial sources, production, and applications. In Frontiers in Microbiology, (Vol. 6, Issue APR). Frontiers Media S.A. https://doi.org/10.3389/fmicb.2015.00288

Sathiyanarayanan, G. ; K. Dineshkumar and Y.H. Yang (2017). Microbial exopolysaccharide-mediated synthesis and 
stabilization of metal nanoparticles. Critical Reviews in Microbiology, 43(6): 731-752.

Shukla, V. and M. Patel (2015). Duggirala. Isolation, structural characterization and production of exopolysaccharide producing batch culture of Bacillus species isolated from the soil. International Journal of Research in Engineering and Applied Sciences, 3(2): 102-109.

Sirajunnisa, A. R. and D. Surendhiran (2014). Nanosilver fabrication mediated by exopolysaccharides from Pseudomonas fluorescens and its biological activities. Magnesium, 5(6).

Sterner, R. W. ; T. Andersen ; J.J. Elser ; D.O. Hessen ; J. M.Hood ; E. McCauley and J. Urabe (2008). Scale-dependent carbon: nitrogen: phosphorus seston stoichiometry in marine and freshwaters. Limnology and Oceanography, 53(3): 1169-1180.

Wang, C. ; Q.Fan ; X.Zhang ; X. Lu ; Y.Xu ; W. Zhu ; J.Zhang ; W. Hao and L. Hao (2018). Isolation, characterization, and pharmaceutical applications of anexopolysaccharide from aerococcus uriaeequi. Marine Drugs, 16(9). https://doi.org/10.3390/md16090337. 
• اظهرت نتائجنا ان سلآله بكتيريه واحده فقط من تربه القمح لديها القدره علي انتاج السكريات

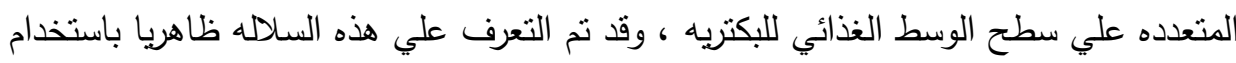

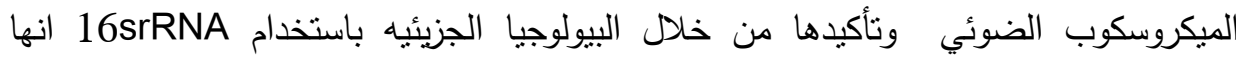
مطابقه ل Bacillus spp، تم استخلاص السكريات المتعدده التي نم انتاجها بواسطه هذه

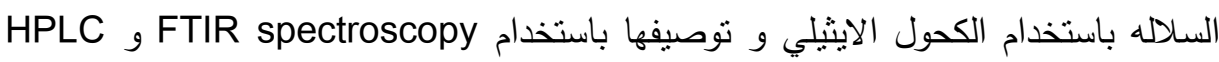

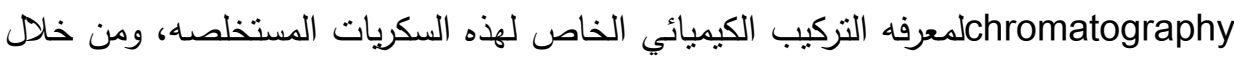
هذه الدراسه يمكن فتح الباب الي استخدام Bacillus spp كمصدر طبيعيا واعد لانتاج

EPS 